\title{
Microclimate Modification and Insect Pest Exclusion Using Agronet Improve Pod Yield and Quality of French Bean
}

\author{
Elisha Otieno Gogo, Mwanarusi Saidi, and Jacob Mugwa Ochieng \\ Department of Crops, Horticulture and Soils, Egerton University, P.O. Box \\ 536, Egerton, Kenya
}

\section{Thibaud Martin}

CIRAD UR Hortsys, Avenue Agropolis, 34398 Montpellier Cedex 5, France; and Icipe, Plant Health Department, P.O. Box 30772-00100, Nairobi, Kenya

\author{
Vance Baird and Mathieu Ngouajio ${ }^{1,2}$ \\ Department of Horticulture, Michigan State University, 1066 Bogue Street, \\ Plant and Soil Science Building, East Lansing, MI 48824
}

Additional index words. eco-friendly nets, environmental manipulation, pest control, protected cropping, snap bean

\begin{abstract}
French bean [Phaseolus vulgaris (L.)] is among the leading export vegetable in Africa, mostly produced by small-scale farmers. Unfavorable environmental conditions and heavy infestations by insect pests are among the major constraints limiting production of the crop. Most French bean producers grow their crop in open fields outdoors subject to harsh environmental conditions and repeatedly spray insecticides in a bid to realize high yield. This has led to rejection of some of the produce at the export market as a result of stringent limits on maximum residue levels. Two trials were conducted at the Horticulture Research and Teaching Field, Egerton University, Kenya, to evaluate the potential of using agricultural nets (herein referred to as agronets) to improve the microclimate, reduce pest infestation, and increase the yield and quality of French bean. A randomized complete block design with five replications was used. French bean seeds were direct-seeded, sprayed with an alpha-cypermethrin-based insecticide (control), covered with a treated agronet $(0.9 \mathrm{~mm} \times 0.7 \mathrm{~mm}$ average pore size made of 100 denier yarn knitted into a mesh impregnated with alpha-cypermethrin), or covered with an untreated-agronet $(0.9 \mathrm{~mm} \times 0.7 \mathrm{~mm}$ average pore size made of 100 denier yarn knitted into a mesh not impregnated with insecticide). Alpha-cypermethrin and agronets were manufactured by Tagros Chemicals (India) and $A$ to $Z$ Textile Mills (Tanzania), respectively. Covering French bean with the agronets modified the microclimate of the growing crop with air temperature increased by $\approx 10 \%$, relative humidity by $4 \%$, and soil moisture by $20 \%$, whereas photosynthetic active radiation $(P A R)$ and daily light integral (DLI) were decreased by $\approx 1 \%$ and $11.5 \%$, respectively. Populations of silverleaf whitefly [Bemisia tabaci (Gennadius)] and black bean aphids [Aphis fabae (Scopoli)] were reduced under agronet covers as contrasted with control plots. Furthermore, populations of both pests were reduced on French bean grown under impregnated agronets compared with untreated agronets, but only on three of the five sampling dates [30, 44, and 72 days after planting (DAP)] for silver leaf whitefly or at only one of the five sampling dates (30 DAP) for black bean aphid. Covering French bean with agronets advanced seedling emergence by 2 days and increased seedling emergence over $90 \%$ compared with control plots. French bean plants covered with both agronet treatments had faster development, better pod yield, and quality compared with the uncovered plants. These findings demonstrate the potential of agronets in improving French bean performance while minimizing the number of insecticide sprays within the crop cycle, which could lead to less rejection of produce in the export market and improved environmental quality.
\end{abstract}

French bean [Phaseolus vulgaris (L.)] is one of the most important introduced vegetable crops in the socioeconomic farming systems of eastern Africa. It is a crop with great potential for addressing food insecurity, income generation, and poverty alleviation in the region (Monda et al., 2003). In Kenya, French bean is the most important export vegetable crop. Estimates indicate that up to 50,000 small-holder families are involved in French bean production in the country
(HCDA, 2011). In the year 2010, the crop accounted for $54 \%$ of the total volume of vegetables exported from the country at a total value of Kshs. 4.3 billion ( $\$ 5$ million) (HCDA, 2011). Other east African countries with an increasing potential for French bean production are Uganda, Tanzania, and Rwanda (Kimani et al., 2004).

In most of these countries, production of the crop is dominated by rural small-scale farmers with most of them being women and children. French bean is therefore a major source of income and employment among these groups (Wahome et al., 2011). Besides east Africa, French bean is widely cultivated in temperate and subtropical regions and in other parts of the tropics (Purseglove, 1987). Apart from its lucrative market, the vegetable is generally popular for its high nutritional content, being rich in protein, calcium, iron, and vitamins (Kelly and Scott, 1992). However, despite all the impressive statistics, realization of maximum benefits by French bean growers is hampered by various challenges. Among the major challenges cited for French bean production are unfavorable environmental conditions and insect pest problems (Monda et al., 2003) with the latter further confirmed by a bean value chain analysis study conducted in Kenya by The Netherlands Development Organization and Fineline Systems in 2012.

In the past, indiscriminate application of pesticides has been the norm among many growers in a bid to realize higher yield (Dinham, 2003). However, emerging food safety and quality issues in the European market (EU) have led to stringent standards for fresh fruits and vegetables entering the EU. The EU, which is Kenya's largest market, has placed some Kenyan horticultural products including French bean on "high-risk" status and implemented inspection and sampling at European designated points of entry where samples are to be analyzed for the presence of pesticide residues before the consignments are released into the market (HCDA, 2011). This testing revealed that a majority of small-holder French bean producers were noncompliant with market requirements, resulting in interception of their produce in the international market. In addition, fear of maximum residue level (MRL) noncompliance discourages exporters from buying French bean from small-holders (Henson et al., 2008). Thus, with the amount of insecticide used becoming increasingly unacceptable, alternative measures of pest control need to be implemented if French bean is to maintain its vital position in improving livelihoods of the rural poor. The use of agronets represents a technology with a potential of not only providing resource-poor farmers with low cost pest control, but also for better crop performance through modified crop microclimate. Studies in Benin-West Africa have reported lower populations of diamondback moth [Plutella xylostella (L.)], aphid [Lipaphis erysimi (Kaltenbach)], and borer [Hellula undalis (Fabricius)] on cabbage grown under nets compared with the use of foliar insecticide or unsprayed controls (Licciardi et al., 2008; Martin et al., 2006). In Kenya-East Africa, net covers have also proved effective in reducing insect pest pressure and modifying the nursery microclimate leading to improved tomato [Solanum lycopersicum (L.)] (Gogo et al., 2012) and cabbage [Brassica oleracea (L.) var. capitata (L.)] (Muleke et al., 2013) seedling growth and quality. Martin et al. $(2013,2014)$ showed higher efficacy against aphids and whitefly with an alpha-cypermethrin-treated net compared 
with a non-treated net. We also showed the potential of agronet in modifying microclimate conditions and improving yields and quality of tomato under tropical field conditions (Saidi et al., 2013). The use of agronets increased both total and marketable yields compared with open-field production. Fruit from plants covered with agronets had higher total soluble solids, lower titratable acidity, and higher sugar-to-acid ratio.

Increasing yield and supplying French bean with quality characteristics demanded by target markets is vital in increasing the consumption and export value of the crop (Kimani et al., 2007). However, as a result of the new requirements relating to environmental sustainability of pesticides and the changing consumer requirements for quality currently demanded by the international market for French bean and other fresh produce, there is need to evaluate other technologies that can help address some of these concerns.

This study evaluated whether growing French beans under agronet (treated or non-treated with an insecticide) covers could reduce insect pest infestation on the crop and the subsequent need for insecticide spray as well as whether agronets positively modified the microclimate leading to improved pod yield and quality.

\section{Materials and Methods}

\section{Experimental site}

Two trials (Sept. to Dec. 2012 and Jan. to Apr. 2013) were conducted at the Horticulture Research and Teaching Field of Egerton University, Njoro, Kenya. The field is located within the coordinates of lat. $0^{\circ} 23^{\prime} \mathrm{S}$ and long. $35^{\circ} 35^{\prime} \mathrm{E}$ in the Lower Highland III Agro Ecological Zone (LH3) at an altitude of $\approx 2238 \mathrm{~m}$ above sea level. The local microclimate conditions are shown in Table 1.

\footnotetext{
Received for publication 21 May 2014. Accepted for publication 26 Aug. 2014.

This study was made possible by the generous support of the American people through the U.S. Agency for International Development (USAID) under Award No. EPP-A-00-09-00004 with additional support from Michigan State University and the Cirad-Agricultural Research for Development. The contents are the responsibility of Horticulture Collaborative Research Support Program (HortCRSP) project BioNetAgro investigators and do not necessarily reflect the views of USAID or the U.S. government.

We acknowledge our project partners: the Kenya Agricultural Research Institute (KARI) and the International Centre of Insect Physiology and Ecology (Icipe) in Kenya; A to Z Textile Mills in Tanzania; and University of Abomey Calavi, Institut National des Recherches Agricoles du Bénin (INRAB) and Association des Personnes Rénovatrices des Technologies Traditionnelles (APPRETECTRA) in Benin for their support. ${ }^{1}$ Current address: USDA-NIFA (National Institute of Food and Agriculture), Institute of Food Production and Sustainability, 800 9th Street, SW, Washington, DC 20024.

${ }^{2}$ To whom reprint requests should be addressed; e-mailmngouajio@nifa.usda.gov.
}

Soils are predominantly andosols with a $\mathrm{pH}$ of 6.0 to 6.5 (Jaetzold and Schmidt, 2006).

\section{Planting material}

French bean seeds of the cultivar Samantha were used [Amiran (K) Ltd., Nairobi, Kenya]. 'Samantha' is a determinate variety and one of the most popular among French bean growers in the country.

\section{Agronet properties}

The agronets used were made from high-density polyethylene fully recyclable monofilament of 100 denier knitted into a mesh. The nets were white in color with average pore size of $0.9 \mathrm{~mm} \times 0.7 \mathrm{~mm}$. They were ultraviolet protected for extended shelf life with $\approx 90 \%$ light transmittance.

\section{Experimental design and treatments}

The experiment was laid out in a randomized complete block design with five replications and three treatments; open field-sprayed with insecticides (alpha-cypermethrin from Tagros Chemicals, India) as the standard practice by French bean growers (control), under an agronet cover not impregnated with alpha-cypermethrin (untreated), and under an agronet cover impregnated with alpha-cypermethrin (treated agronet). Each block measured $17 \mathrm{~m} \times 10 \mathrm{~m}$ separated by a 1-m buffer from each other. Each experimental unit measured $1.5 \mathrm{~m} \times 3 \mathrm{~m}$. Before planting, poles $0.75 \mathrm{~m}$ long and $\approx 5 \mathrm{~cm}$ thick were installed in plots that were to be covered with agronets to provide support for the net covers. The poles were driven $25 \mathrm{~cm}$ deep to the ground at each corner and at the center of the plot to anchor them. Binding wire was then fixed at the top of the posts along the perimeter and the center of the plots using u-nails. Agronet measuring $3 \mathrm{~m}$ wide $\times 4 \mathrm{~m}$ long were then mounted on each plot completely covering the plots (Fig. 1). Once covered, plots were only opened for routine plant management and data collection periods.

\section{Land preparation and plot maintenance}

The field was manually dug using hand hoes to $\approx 20$-cm depth and prepared to a fine tilth using a fine tooth rake. Drills were then made $30 \mathrm{~cm}$ apart giving a total of five rows in each plot. Diammonium phosphate $[18 \%$ nitrogen $(\mathrm{N}), 46 \% \mathrm{P}_{2} \mathrm{O}_{5}$ ] was then applied at a rate of $200 \mathrm{~kg} \cdot \mathrm{ha}^{-1}\left(6 \mathrm{~g} \cdot \mathrm{m}^{-1}\right.$ of bed $)$ and thoroughly mixed with soil before seeding. Seeds were sown at a spacing of $30 \mathrm{~cm}$ between rows and $10 \mathrm{~cm}$ within the rows giving a total of 150 plants per experimental unit (30 plants $\left./ \mathrm{m}^{2}\right)$. The first cropping period was from 3 Sept. to 21 Dec. 2012 and the second from 3 Jan. to 22 Apr. 2013. Calcium ammonium nitrate $(26 \% \mathrm{~N})$ was later applied as a top dressing at a rate of $200 \mathrm{~kg} \cdot \mathrm{ha}^{-1}$ in an equal split application, at the trifoliate leaf stage and at onset of flowering as recommended by MOARD (Ministry of Agriculture and Rural Development, 2003). Control plots were sprayed with alpha-cypermethrin $\left(100 \mathrm{~g} \cdot \mathrm{L}^{-1} \mathrm{EC}\right.$ from Tagros
Chemicals) at a recommended rate of $25 \mathrm{~mL}$ of formulation of alpha-cypermethrin in $20 \mathrm{~L}$ of water with a total of six sprays (calendar-based) made during each crop cycle. The agronet treatments on the other hand received only one insecticide spray applied at the mid-vegetative growth stage because pest pressure did not justify additional treatments. Weeding was done as needed. The crop was predominantly rain-fed but during extended dry spells, watering was done manually using watering cans ensuring that an equal amount of water was applied in each experimental unit.

\section{Data collection}

Eight plants from the central rows of each experimental unit were randomly selected for collection of data on pest counts, plant development, and yield.

Microclimate. WatchDog Plant Growth Station data loggers (2475; Spectrum Technologies, Plainfield, IL) were used in each plot to collect microclimate data. The data loggers were programmed to collect data at $15-\mathrm{min}$ intervals and average it on a fortnightly basis. Data collected included air temperature $\left({ }^{\circ} \mathrm{C}\right)$ and relative humidity (\%), PAR, DLI, and soil moisture as volumetric water content (\%) using an external sensor (WaterScout ${ }^{\mathrm{TM}}$ SM 100; Spectrum Technologies).

Pest counts. The major insect pests observed were black bean aphids [Aphis fabae (Scopoli)] and silverleaf whiteflies [Bemisia tabaci (Gennadius)]. The number of black bean aphids at the nymph stage $(\approx 2 \mathrm{~mm}$ in size $)$ and adult silverleaf whiteflies $(\approx 1.5 \mathrm{~mm}$ in size) were counted once every 2 weeks early in the morning when the pests were inactive.

Plant development. The number of days to first emergence of French bean was recorded. Thereafter, seedling numbers were counted at 2-d intervals for a week and the progressive percentages computed for each treatment. The number of leaves and branches was also counted every 2 weeks.

Yield and yield components. On the onset of flowering, flower and pod numbers per plant were counted and recorded at a 2 -week interval. At the green pod maturity stage, the crop was harvested daily for 3 weeks. At each harvest, the number of pods from each plant was counted for each treatment and their weight determined. Five pods were then randomly sampled from the harvest of each treatment for determination of pod length and pod thickness in millimeters.

\section{Data analysis}

The Proc univariate procedure of SAS (Version 9.1; SAS Institute, Cary, NC) was used to control for normality of the data before analysis. Initial analysis showed no significant interaction between treatments and season for most variables measured. Data were thus pooled and subjected to analysis of variance using the GLM procedure at $P \leq$ 0.05 . The data were analyzed using the statistical model: $Y i j=\mu+\beta i+\alpha j+\varepsilon i j$ where; Y $i j$ is the French bean response, $\mu$ is the 
Table 1. Mean monthly values of local climatic conditions during French bean production under agronets across two seasons (Sept. to Dec. 2012 and Jan. to Apr. 2013).

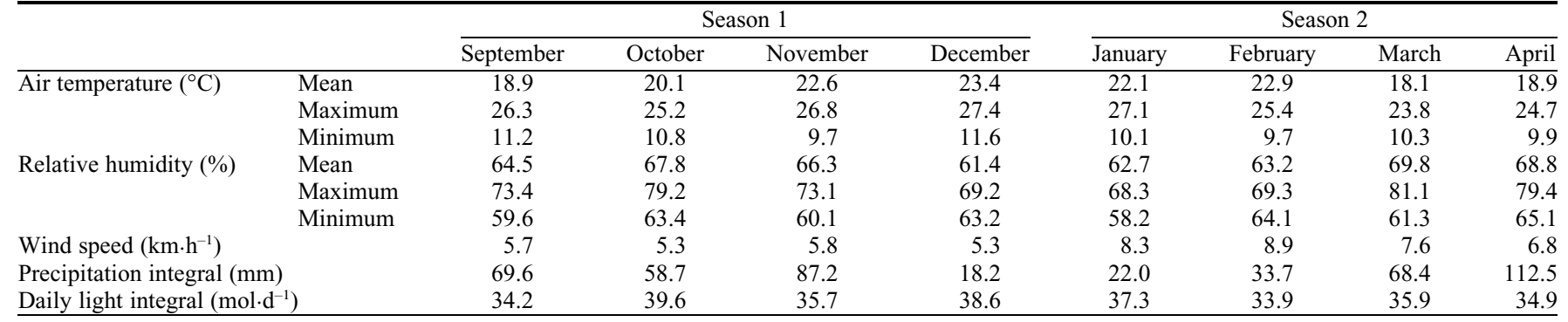

Source: Egerton University Engineering Department (2013).

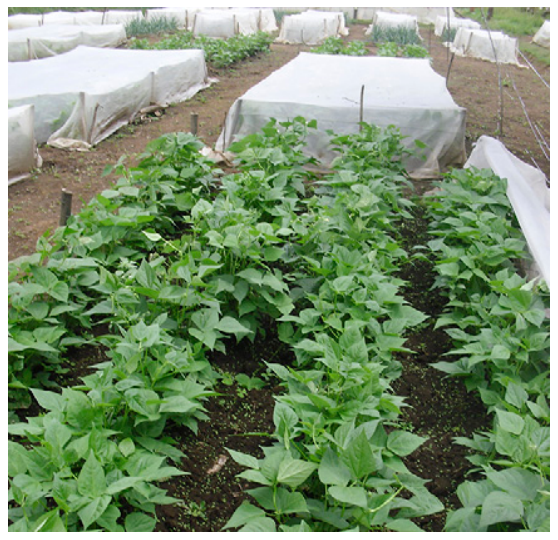

Fig. 1. Experimental layout showing support structure and agronet covers on French bean crop in 2012 and 2013.

overall mean, $\beta i$ is the $i^{\text {th }}$ blocking effect, $\alpha j$ is the effect resulting from the $\mathrm{j}^{\text {th }}$ agronet cover, and $\varepsilon i j$ is the random error term. Means for significant treatments at the $\mathrm{F}$ test were separated using Tukey's honestly significant difference test at $P \leq 0.05$.

\section{Results}

Microclimate. Covering French bean with agronets modified the microclimate for the growing crop. Air temperature, relative humidity, and soil moisture (measured in volumetric water content) remained higher under agronet-covered plots compared with the uncovered control throughout the evaluation period (Fig. 2). Averaged over each growing season, air temperature was $22.7^{\circ} \mathrm{C}$ under treated agronet and $22.6{ }^{\circ} \mathrm{C}$ under untreated agronets in the first season compared with $20.4{ }^{\circ} \mathrm{C}$ under the control. In the second season, $24.4{ }^{\circ} \mathrm{C}$ was recorded under both treated agronet and untreated agronets compared with $22.2{ }^{\circ} \mathrm{C}$ under the control representing $\approx 10 \%$ increase in air temperature under the agronets. Relative humidity was $68.9 \%$ under treated agronet and $69.0 \%$ under untreated agronet compared with $66.9 \%$ under the control in the first season and $68.4 \%$ under treated agronet and $68.6 \%$ under untreated agronet compared with $65.0 \%$ under the control in the second season presenting an $\approx 4 \%$ increase in relative humidity under the agronet. Soil moisture was $26.8 \%$ under both treated and untreated agronets compared with
$21.8 \%$ under the control treatment in the first season and $29.4 \%$ under both treated and untreated nets compared with $24.9 \%$ under the control treatment in the second season presenting an $\approx 20 \%$ increase in soil moisture under agronets.

To the contrary, the use of agronets reduced PAR and DLI (Fig. 3) reaching the crop throughout the study period. Averaged over each growing season, $P A R$ was 587.04 and $587.32 \mathrm{mmol} \cdot \mathrm{m}^{-2} \cdot \mathrm{s}^{-1}$ under treated and untreated agronets, respectively, compared with $593.8 \mathrm{mmol} \cdot \mathrm{m}^{-2} \cdot \mathrm{s}^{-1}$ under open plots (control) in the first season. In the second season, $601.14,601.96$, and $607.98 \mathrm{mmol} \cdot \mathrm{m}^{-2} \cdot \mathrm{s}^{-1}$ were recorded under treated agronet, untreated agronets, and the control, respectively, which presents an $\approx 1 \%$ decrease in the amount of $P A R$ reaching the crops under agronet. Similarly, lower DLI was recorded under the treated agronets $\left(32.2 \mathrm{~mol} \cdot \mathrm{d}^{-1}\right)$ and untreated agronets $\left(32.6 \mathrm{~mol} \cdot \mathrm{d}^{-1}\right)$ compared with the control in the first season $\left(36.9 \mathrm{~mol} \cdot \mathrm{d}^{-1}\right)$. In the second season, 32.0 and $32.1 \mathrm{~mol} \cdot \mathrm{d}^{-1}$ were recorded under the treated and untreated agronets, respectively, whereas DLI under the control was $35.9 \mathrm{~mol} \cdot \mathrm{d}^{-1}$ representing an $\approx 11.5 \%$ decrease in DLI under agronets.

Plant development. The use of agronets significantly advanced days from planting to first emergence of French bean (Fig. 4). French bean sown under both treated and untreated agronet emerged 6 DAP, whereas those planted in the open took $8 \mathrm{~d}$ to emerge. Agronet covers also influenced percent emergence with treated and untreated agronets resulting in higher emergence at all sampling dates and percentage final seedling emergence compared with the control (Fig. 4). Subsequent French bean plant development was also improved by the use of agronet covers as marked by higher leaf numbers and more branches in plants under agronet treatments compared with control plants (Table 2). Except for the initial day of data collection (31 DAP) when the treated and the untreated agronets resulted in no statistical difference, French bean plants covered with the treated agronet had more leaves than those under untreated nets. The number of branches per plant followed a trend similar but the difference between treated and untreated agronet-covered plants was not significant throughout the study.

Pest populations. The use of agronet reduced the numbers of the silverleaf whitefly and black bean aphid (Fig. 5). Except at 58 and 86 DAP when the populations of the silverleaf whiteflies recorded on plants under the treated and the untreated agronet covers were not different, the population of the silverleaf whitefly was significantly lower under the treated agronet. Although a lower black bean aphid population was observed under treated than untreated agronet in all sampling dates, the difference was statistically significant only at 30 DAP.

Yield and yield components. Plants grown under agronet covers produced more flowers than control plants at all sampling dates (Table 3). Except at 31 DAP when flower numbers under the untreated and the treated agronet-covered plots were not different, plants under the treated agronet cover had more flowers. Plants grown under agronet covers had more pods than the control plants throughout the study. Higher total pod numbers and weight were recorded for agronetcovered treatments compared with the control treatment. Total pod numbers increased by $\approx 30 \%$, whereas total pod weight increased by $\approx 40 \%$ under the nets compared with the control (Table 4). Agronets also enhanced pod quality with longer and thicker pods within the export quality range of diameter $9 \mathrm{~mm}$ or less and length $10 \mathrm{~mm}$ or greater [MOA and JICA (Ministry of Agriculture in Conjunction with Japan International Co-operation Agency), 2000] compared with the control. Pods produced under agronets were $\approx 30 \%$ longer and $20 \%$ thicker than those of the control treatment.

\section{Discussion}

This study demonstrated the potential use of agronet covers in protecting a French bean from insect pests as well as in modifying the microclimate to favor development, yield, and quality of the crop. Regardless of whether the cover was treated or untreated, mean daily temperature, relative humidity, and soil moisture remained higher under the agronet treatments compared with the control treatment. Air temperatures were on average increased by $\approx 10 \%$, relative humidity by $\approx 4 \%$, and soil moisture by $\approx 20 \%$ after the use of either treated or untreated agronet covers. Screen covers have shown to alter the exchange of radiation momentum and mass between the crop and the atmosphere hence modifying the crop microclimate (Lloyd et al., 2004). Screens reduce the 

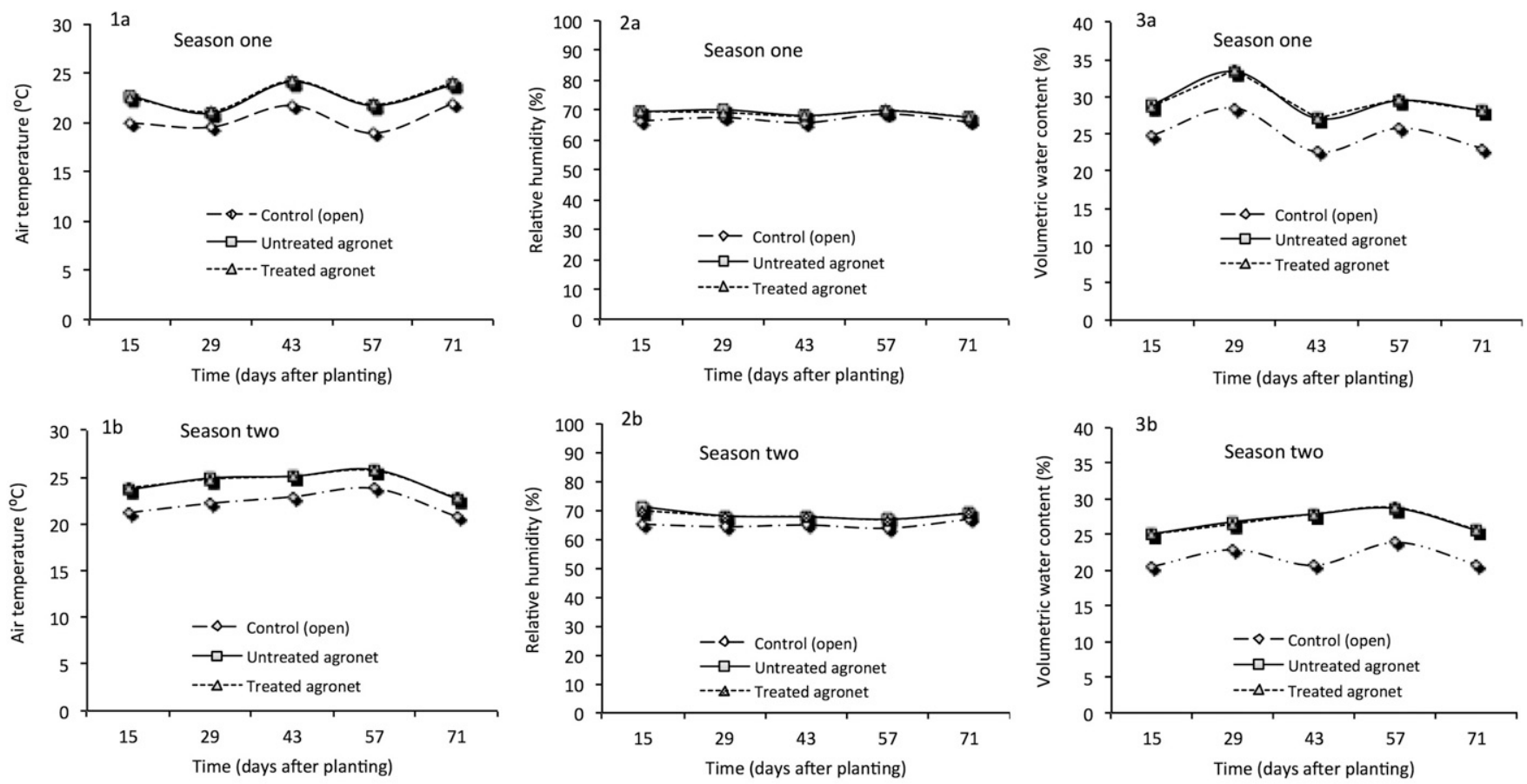

Fig. 2. Effects of agronet covers on air temperature (1a-b), relative humidity $(\mathbf{2} \mathbf{a}-\mathbf{b})$, and volumetric water content $(\mathbf{3 a}-\mathbf{b})$ during production of French bean in two seasons (Sept. to Dec. 2012 and Jan. to Apr. 2013). The control treatment was sprayed with insecticide as a standard practice done by farmers for insect pest management, treated agronet was impregnated with alpha-cypermethrin, and untreated agronet was not impregnated with any insecticide $18{ }^{\circ} \mathrm{C}+32={ }^{\circ} \mathrm{F}$.
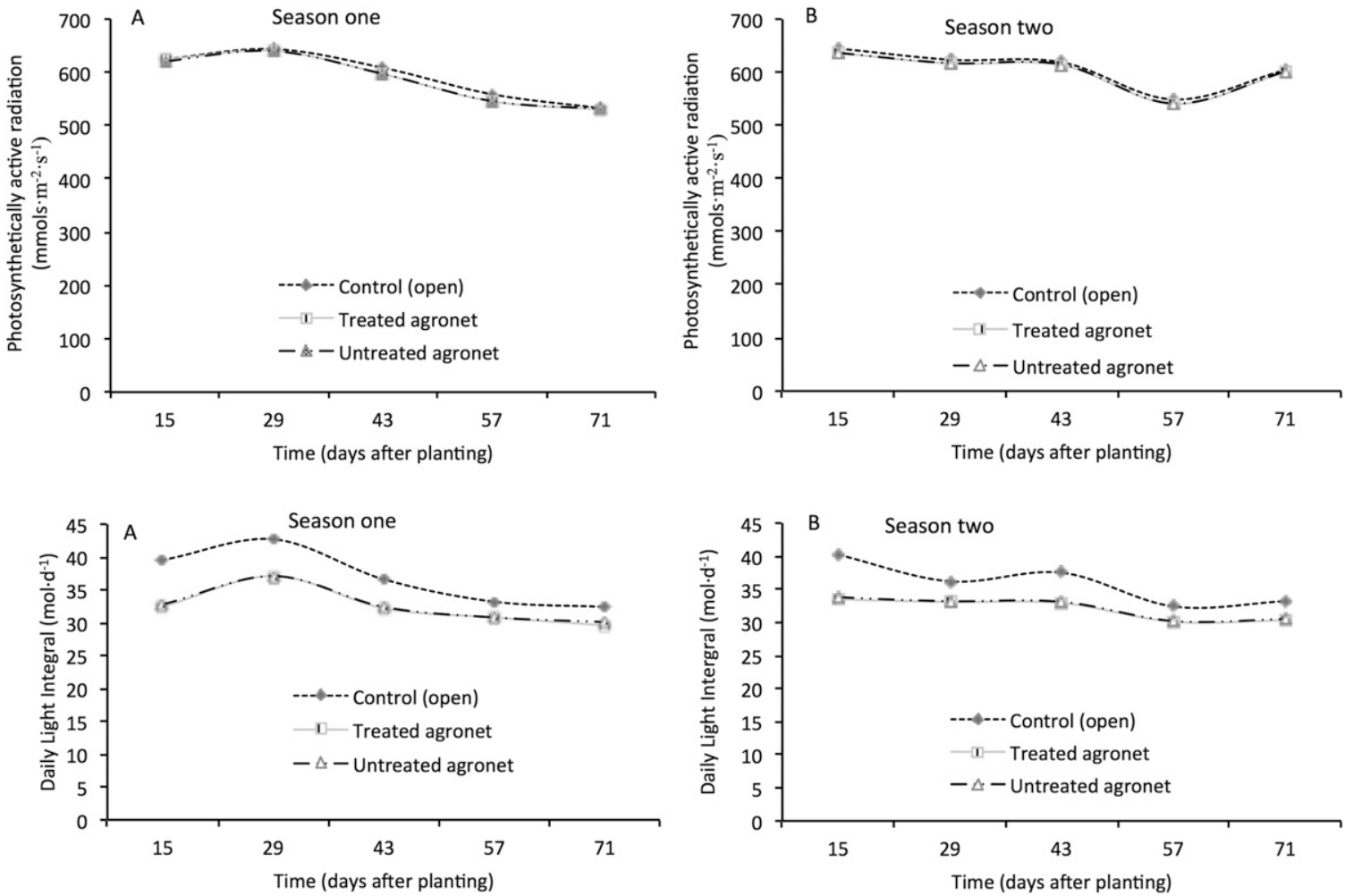

Fig. 3. Effects of agronet covers on photosynthetically active radiation (A) and daily light integral (B) during production of French bean in the two seasons (Sept. to Dec. 2012 and Jan. to Apr. 2013). The control treatment was sprayed with insecticide as a standard practice done by farmers for insect pest management, treated agronet was impregnated with alpha-cypermethrin, and untreated agronet was not impregnated with any insecticide.

mixing of outside and inside air, hence effectively reducing loss of heat to the surrounding atmosphere, which leads to a temperature increase (Tanny et al., 2003). In addition, covering crops reduces instantaneous solar radiation through shading (Waterer et al.,
2003), which lowers evaporation from the ground, thus maintaining higher soil moisture contents (Moreno et al., 2002). Findings of our study corroborate those of earlier studies on tomato and cabbage seedling production under eco-friendly net covers
(Gogo et al., 2012; Muleke et al., 2013; Saidi et al., 2013).

Contrary to temperature, relative humidity, and moisture levels, $P A R$ and light quantities that reached the French bean crop (DLI) were lowered by $\approx 1 \%$ and $11.5 \%$, 

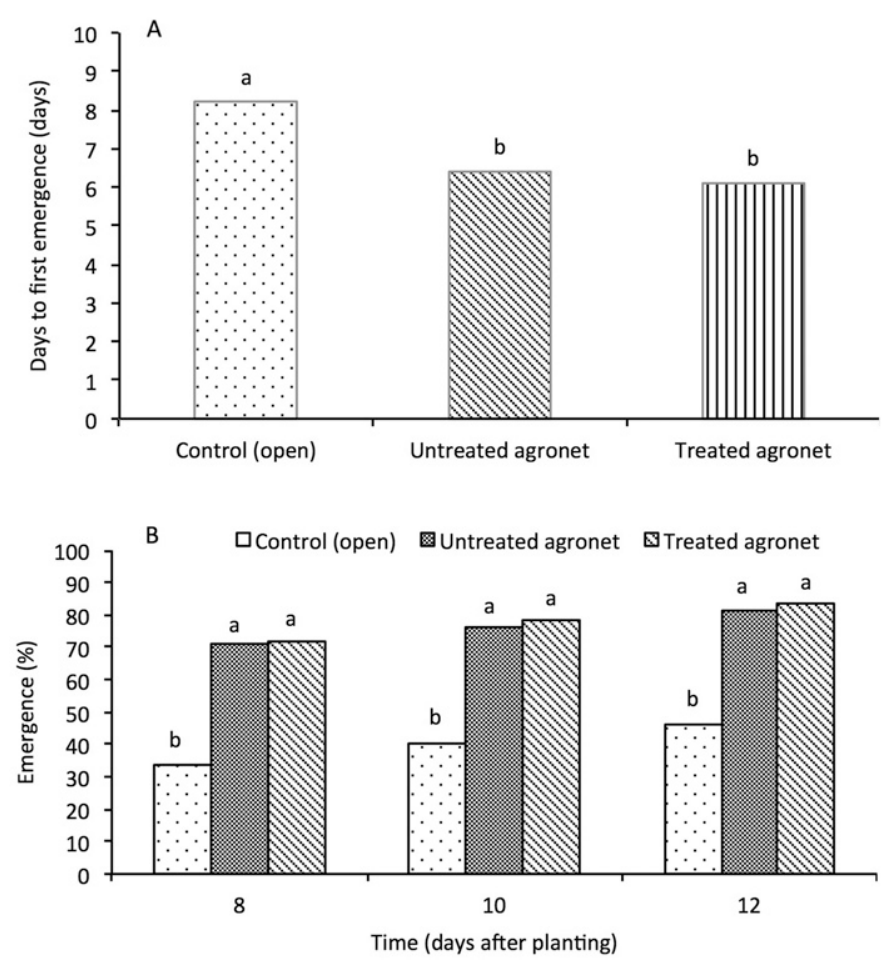

Fig. 4. Effect of agronet covers on days to first emergence (A) and percent emergence (B) of French bean during production. The values presented were averaged across the two seasons (Sept. to Dec. 2012 and Jan. to Apr. 2013). The control treatment was sprayed with insecticide as a standard practice done by farmers for insect pest management, treated agronet was impregnated with alpha-cypermethrin, and untreated agronet was not impregnated with any insecticide. Data points within the same date and parameter followed by the same letter are not significantly different according to Tukey's honestly significant difference at $P \leq 0.05$.

Table 2. Effects of agronet cover on the growth of French bean. ${ }^{z}$

\begin{tabular}{|c|c|c|c|c|c|c|}
\hline \multirow[b]{2}{*}{ Treatment $t^{y}$} & \multicolumn{3}{|c|}{$\begin{array}{l}\text { Leaves (no./plant) } \\
\text { Days after planting }\end{array}$} & \multicolumn{3}{|c|}{$\begin{array}{l}\text { Branches (no./plant) } \\
\text { Days after planting }\end{array}$} \\
\hline & 31 & 45 & 59 & 31 & 45 & 59 \\
\hline Control & $7.25 b^{x}$ & $11.73 \mathrm{c}$ & $12.65 \mathrm{c}$ & $1.90 \mathrm{~b}$ & $2.50 \mathrm{~b}$ & $3.00 \mathrm{~b}$ \\
\hline $\begin{array}{r}\text { Untreated } \\
\text { agronet }\end{array}$ & $10.68 \mathrm{a}$ & $16.85 \mathrm{~b}$ & $18.30 \mathrm{~b}$ & $2.50 \mathrm{a}$ & $3.63 \mathrm{a}$ & $4.25 \mathrm{a}$ \\
\hline Treated agronet & $11.18 \mathrm{a}$ & $18.55 \mathrm{a}$ & $19.80 \mathrm{a}$ & $2.70 \mathrm{a}$ & $3.78 \mathrm{a}$ & $4.48 \mathrm{a}$ \\
\hline$P$ value & $<0.0001$ & $<0.0001$ & $<0.0001$ & 0.0006 & $<0.0001$ & $<0.0001$ \\
\hline $\mathrm{CV}$ & 6.18 & 4.70 & 4.79 & 8.43 & 4.35 & 4.87 \\
\hline
\end{tabular}

${ }^{\mathrm{z}}$ The values presented were averaged across two seasons (Sept. to Dec. 2012 and Jan. to Apr. 2013).

${ }^{\mathrm{y}}$ Control treatment was sprayed with alpha-cypermethrin insecticide as a standard practice done by farmers for insect pest management, treated agronet was impregnated with alpha-cypermethrin, and untreated agronet was not impregnated with any insecticide.

${ }^{\times}$Means followed by the same letter within a column and a parameter are not significantly different according to Tukey's honestly significant difference at $P \leq 0.05$.

respectively, by the use of agronet covers. Covers block light as well as reduce the light quality (Antignus and Ben-Yakir, 2004). The reduction in $P A R$ and light quantity under agronet covers observed in the current study could, therefore, be attributed to the lightblocking properties of the materials used. Although the use of agronet covers lowered $P A R$ and DLI reaching the crop, the quantities received by the crop still remained within acceptable range and did not have a major impact on the plants.

Covering French bean with agronets reduced populations of silverleaf whitefly and black bean aphid and reduced the number of pesticide sprays. Although the control received six sprays, agronet treatments were sprayed only once. The barrier provided by net covers disrupts feeding and mating habits of many pests, thereby lowering their population (Martin et al., 2006). According to Antignus and Ben-Yakir (2004), the light spectrum plays an important role in aspects of insect behavior including navigation and orientation. In the current study, French beans grown under white agronet covers had lower silverleaf whitefly and black bean aphid population sizes than the unprotected control. This may have been as a result of the white bright color of the nets used, which might have served as a visual barrier in addition to the physical barrier provided by the netting material (Gogo et al., 2014). Among agronet-covered plots, plants under the treated agronet covers had the lowest population of the silverleaf whitefly and black bean aphid confirming previous results (Martin et al., 2013, 2014). As stated earlier, the treated agronet was impregnated with alpha-cypermethrin, a non-systemic compound with a repellent and a toxic contact action that has been used as an active ingredient for many commercially sold insecticides.

Air temperatures, relative humidity, and soil moisture levels, on the other hand, remained higher in agronet-covered treatments compared with open-field production. Temperature and soil moisture increases within the optimal range of any given crop has been reported to play a major role in seed germination, enhancing water imbibition and enzyme activation, which leads to better seed germination (van Bruggen et al., 1986). In our study, French bean seedling emergence was advanced by $2 \mathrm{~d}$, and emergence was over $90 \%$ the use of agronet covers. It is therefore possible that the modified microclimate observed under agronets could have favored the seed germination process leading to the early and higher seedling emergence observed. The physical barrier provided by agronet treatments may also prevent birds from feeding on the seedlings. After seedling emergence, French bean plants grown under treated or untreated agronets exhibited better development as measured by production of more leaves and branches compared with the control. On crop maturity, French bean grown under net covers also produced more flowers and pods and had higher yield and pod quality compared with the control. Temperature and moisture are important in photosynthesis during which dry matter is produced and transported to the sinks (Berry and Bjorkman, 1980 ) as well as in the general physiological development of any given crop (Saidi et al., 2013). The higher air temperatures and moisture conditions recorded under agronet covers in the current study probably favored these processes in the French bean crop leading to the better crop performance observed under agronet covers. In addition, sucking pests are also known to directly affect crop performance through sucking of plant sap or indirectly through transmission of viral diseases. It is therefore possible that the better growth and higher yield and pod quality observed in our study could partly have been as a result of the significant reduction in silverleaf whitefly and black bean aphid under the agronet covers. Similar to these observations, Gogo (2013) reported better physiological development, reduced insect pest attack, and higher yield and quality tomato from plants grown under net covers compared with open-field production.

\section{Conclusion and Recommendations}

These results demonstrate the potential of agronet covers as a viable strategy for improving French bean yield and quality through improvement of the microclimate around growing French bean crop as well as reducing insect pest attack. Although the use of alpha-cypermethrin-treated agronets managed insect pests better than the untreated agronets, based on study results, we recommend the use of the untreated agronet to avoid the additional cost entailed in producing impregnated agronets with no additional 

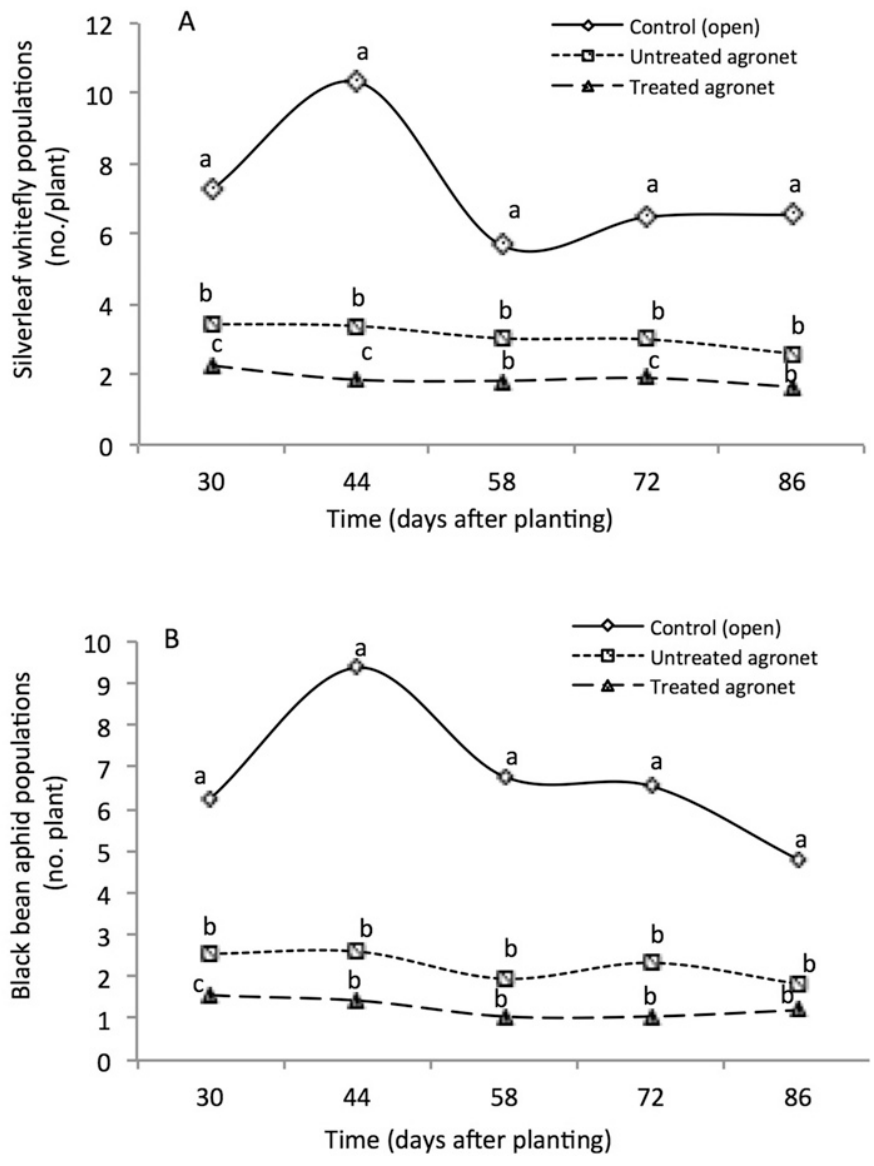

Fig. 5. Effects of agronet covers on the population of silverleaf whitefly (A) and black bean aphid (B) during the production of French bean. The values shown were averaged across the two seasons (Sept. to Dec. 2012 and Jan. to Apr. 2013). The control treatment was sprayed with alpha-cypermethrin insecticide as a standard practice done by farmers for insect pest management, treated agronet was impregnated with alpha-cypermethrin, and untreated agronet was not impregnated with any insecticide. Data points within the same date and parameter followed by the same letter are not significantly different according to Tukey's honestly significant difference at $P \leq 0.05$.

Table 3. Effects of agronet cover on flower (no./plant) and green pods (no./plant) of French bean. ${ }^{\mathrm{z}}$

\begin{tabular}{lccccccc}
\hline & \multicolumn{3}{c}{$\begin{array}{c}\text { Flowers (no./plant) } \\
\text { Days after planting }\end{array}$} & & \multicolumn{3}{c}{$\begin{array}{c}\text { Pods (no./plant) } \\
\text { Days after planting }\end{array}$} \\
\cline { 2 - 4 } \cline { 6 - 8 } Treatment & 31 & 45 & 59 & & 45 & 59 & 73 \\
\hline Control & $14.43 \mathrm{~b}^{\mathrm{x}}$ & $18.33 \mathrm{c}$ & $9.50 \mathrm{c}$ & & $14.70 \mathrm{~b}$ & $17.80 \mathrm{~b}$ & $14.65 \mathrm{~b}$ \\
Untreated agronet & $18.73 \mathrm{a}$ & $24.70 \mathrm{~b}$ & $14.33 \mathrm{~b}$ & & $17.45 \mathrm{a}$ & $23.93 \mathrm{a}$ & $19.40 \mathrm{a}$ \\
Treated agronet & $19.65 \mathrm{a}$ & $25.88 \mathrm{a}$ & $15.58 \mathrm{a}$ & & $17.70 \mathrm{a}$ & $24.69 \mathrm{a}$ & $19.45 \mathrm{a}$ \\
$P$ value & $<0.0001$ & $<0.0001$ & $<0.0001$ & & $<0.0001$ & $<0.0001$ & 0.0005 \\
$\mathrm{CV}$ & 5.44 & 2.61 & 3.56 & & 2.93 & 2.77 & 7.25 \\
\hline
\end{tabular}

${ }^{\mathrm{z}}$ The values presented were averaged across two seasons (Sept. to Dec. 2012 and Jan. to Apr. 2013).

${ }^{y}$ Control treatment was sprayed with alpha-cypermethrin insecticide as a standard practice done by farmers for insect pest management, treated agronet was impregnated with alpha-cypermethrin, and untreated agronet was not impregnated with any insecticide.

${ }^{x}$ Means followed by the same letter within a column and a parameter are not significantly different according to Tukey's honestly significant difference test at $P \leq 0.05$.

Table 4. Effects of agronet cover on pod yield and quality of French bean. ${ }^{2}$

\begin{tabular}{lccccc}
\hline & \multicolumn{2}{c}{ Pod yield } & & \multicolumn{2}{c}{ Pod quality } \\
\cline { 2 - 3 } \cline { 6 - 6 } Treatment ${ }^{\mathrm{y}}$ & $\begin{array}{c}\text { Total pod } \\
\text { number (no./plant) }\end{array}$ & $\begin{array}{c}\text { Total pod } \\
\text { wt (g/plant) }\end{array}$ & & $\begin{array}{c}\text { Pod length } \\
(\mathrm{cm})\end{array}$ & $\begin{array}{c}\text { Pod thickness } \\
(\mathrm{mm})\end{array}$ \\
\hline Control & $46.89 \mathrm{~b}^{\mathrm{x}}$ & $167.97 \mathrm{~b}$ & & $8.72 \mathrm{~b}$ & $6.3 \mathrm{~b}$ \\
Untreated agronet & $60.43 \mathrm{a}$ & $233.62 \mathrm{a}$ & & $11.61 \mathrm{a}$ & $7.5 \mathrm{a}$ \\
Treated agronet & $61.10 \mathrm{a}$ & $237.99 \mathrm{a}$ & & $11.92 \mathrm{a}$ & $7.6 \mathrm{a}$ \\
$P$ value & $<0.0001$ & $<0.0001$ & & $<0.0001$ & $<0.0001$ \\
$\mathrm{CV}$ & 2.96 & 1.85 & & 2.44 & 1.05 \\
\hline
\end{tabular}

${ }^{\mathrm{z}}$ The values presented were averaged across the two seasons (Sept. to Dec. 2012 and Jan. to Apr. 2013). ${ }^{\mathrm{y}}$ Control treatment was sprayed alpha-cypermethrin with insecticide as a standard practice done by farmers for insect pest management, treated agronet was impregnated with alpha-cypermethrin, and untreated agronet was not impregnated with any insecticide.

${ }^{x}$ Means followed by the same letter within a column and a parameter are not significantly different according to Tukey's honestly significant difference at $P \leq 0.05 .1 \mathrm{~cm}=0.3937 \mathrm{inch} ; 1 \mathrm{~mm}=0.0393 \mathrm{inch}$. benefits accrued in terms of microclimate modification and pod yield and quality. Worker safety and disposal issues associated with the insecticide-impregnated agronets also favors the use of the ones that were not impregnated. The use of agronet covers in French bean production also stands to be of benefit in reducing the number of direct insecticide sprays needed during the production cycle of the crop, which could go along in meeting the MRLs demanded by the international fresh produce markets and contributing to safer food and environmental quality. Although the findings of this study provide a foundation to understand the role agronet covers can play in French bean production, we recommend further studies to test the applicability of the technology on a range of French bean varieties and in different French bean-growing areas. Studies with a wider range of mesh sizes and colors, and impregnated with different groups of insecticides, would also be beneficial. Quantifying the exact reduction in the amount of insecticides used and resulting residue levels in a crop cycle and an evaluation of the effects of the covers on beneficial insects (pollinators and natural enemies) are also recommended. A full economic analysis factoring in the cost of purchase, installation, and management of agronet covers would also be useful.

\section{Literature Cited}

Antignus, Y. and D. Ben-Yakir. 2004. Ultravioletabsorbing barriers, an efficient integrated pest management tool to protect greenhouses from insects and virus disease. In: Rami Horowitz, A. and I. Ishaaya (eds.). Insect pest management: Field and protected crops. Springer, New York, NY.

Berry, J. and O. Bjorkman. 1980. Photosynthetic response and adaptation to temperature in higher plants. Annu. Rev. Plant Physiol. 31:491-643.

Dinham, B. 2003. Growing vegetables in developing countries for local urban populations and export markets: Problems confronting smallscale producers. Pest Mgt. Sci. 59:575-582.

Gogo, E.O. 2013. Influence of eco-friendly nets and floating row cover on microclimate modification, pest infestation, growth and yield of tomato [Lycopersicon esculentum (Mill.)]. MSc thesis, Egerton University, Egerton, Kenya.

Gogo, E.O., M. Saidi, F.M. Itulya, T. Martin, and M. Ngouajio. 2012. Microclimate modification using eco-friendly nets for high quality tomato transplant production by small-scale farmers in east Africa. HortTechnology 22:292-298.

Gogo, E.O., M. Saidi, F.M. Itulya, T. Martin, and M. Ngouajio. 2014. Eco-friendly nets and floating row covers reduce pest infestation and improve tomato [Solanum lycopersicum (L.)] yields for smallholder farmers in Kenya. Agronomy $4: 1-12$.

HCDA. 2011. Horticulture validated report. Agricultural Information Resource Centre, Nairobi, Kenya.

Henson, S., S. Jaffee, J. Cranfield, J. Blandon, and P. Siegel. 2008. Linking African smallholders to high-value markets: Practitioner perspectives on benefits, constraints and interventions. Policy Research Working Paper 4573. Agriculture and Rural Development Department, The World Bank. 
Jaetzold, R. and H. Schmidt. 2006. Farm management handbook of Kenya. Natural conditions and farm information. Vol.11/ C. 2nd Ed. Ministry of Agriculture, East Kenya, Kenya.

Kelly, J.F. and M.K. Scott. 1992. The nutritional value of snap beans versus other vegetables. In: Proc. of an International Conference held in Cali, Colombia, 16-20 Oct. 1989.

Kimani, J.M., P.M. Kimani, S.M. Githiri, and J.W. Kimenju. 2007. Mode of inheritance of common bean [Phaseolus vulgaris (L.)] traits for tolerance to low soil phosphorus. Euphytica 155:225-234.

Kimani, P.M., H. van Rheenen, P. Mathenge, and A. Ndegwa. 2004. Breeding snap beans for smallholder production in east and central Africa, p. 49-51. In: Bean improvement for the tropics, annual report 2004. CIAT, Cali, Colombia.

Licciardi, S., F. Assogba-Komlan, I. Sidick, F. Chandre, J.M. Hougard, and T. Martin. 2008. A temporary tunnel screen as an eco-friendly method for small-scale farmers to protect cabbage crops in Benin. International Journal of Tropical Insect Science 27:152-158.

Lloyd, A.E., A.P. Hamacek, R.J. George, and G. Waite. 2004. Evaluation of exclusion netting for insect pest control and fruit quality enhancement in tree crops. International Journal of Tropical Insect Science 27:3-4.

Martin, T., F. Assogba-komlan, T. Houndete, J.M. Hougard, and F. Chandre. 2006. Efficacy of mosquito netting for sustainable small holder's cabbage production in Africa. J. Econ. Entomol. 99:450-454.
Martin, T., F. Chandre, G. Ochou, M. Vaissayre, and D. Fournier. 2002. Pyrethroid resistance mechanisms in the cotton bollworm [Helicoverpa armigera (Lepidoptera: Noctuidae)] from west Africa. Pestic. Biochem. Physiol. 74:17-26.

Martin, T., E.O. Gogo, M. Saidi, A. Kamal, E. Delétré, R. Bonafos, S. Simon, and M. Ngouajio. 2014. Repellent effect of an alpha-cypermethrin treated net against the whitefly [Bemisia tabaci (Gennadius)]. J. Econ. Entomol. 107: 684-690.

Martin, T., R. Palix, A. Kamal, E. Delétré, R. Bonafos, S. Simon, and M. Ngouajio. 2013. A repellent treated netting as a new technology for protecting vegetable crops. J. Econ. Entomol. 106:1699 1706.

MOA and JICA (Ministry of Agriculture in Conjunction with Japan International Co-operation Agency). 2000. Local and export vegetables growing manual. Agricultural Information Resource Centre, Nairobi, Kenya.

MOARD (Ministry of Agriculture and Rural Development). 2003. Fruits and vegetable technical hand book. Agricultural Information Resource Centre, Nairobi, Kenya.

Monda, E.O., S. Munene, and A. Ndegua. 2003. French beans production constraints in Kenya. African Crop Science Society. African Crop Science Conference Proc. 6:683-687.

Moreno, D.A., G. V1'llora, M.T. Soriano, N. Castilla, and L. Romero. 2002. Floating row covers affect the molybdenum and nitrogen status of chinese cabbage grown under field conditions. Funct. Plant Biol. 29:585-593.
Muleke, E.M., M. Saidi, F.M. Itulya, T. Martin, and M. Ngouajio. 2013. The Assessment of the use of eco-friendly nets to ensure sustainable cabbage seedling production in Africa. Agronomy 3:1-12.

Purseglove, J.W. 1987. Tropical crops. Dicotyledons. Longman, New York, NY. p. 132-136.

Saidi, M., E.O. Gogo, F.M. Itulya, T. Martin, and M. Ngouajio. 2013. Microclimate modification using eco-friendly nets and floating row covers improves tomato [Lycopersicon esculentum (Mill)] yield and quality for small holder farmers in East Africa. Agricultural Sciences 4:577-584.

Tanny, J., S. Cohen, A. Grava, A. Naor, and V. Lukyanov. 2003. The effect of shading screens on microclimate of apple orchards. Chilean Journal 4:347-359.

van Bruggen, A.H.C., C.H. Whalen, and P.A. Arneson. 1986. Emergence, growth and development of dry bean seedlings in response to temperature, soil moisture, and Rhizoctonia Solani. Phytopathology 76:568-572.

Wahome, S.W., P.M. Kimani, J.W. Muthomi, R.D. Narla, and R. Buruchara. 2011. Multiple disease resistance in snap bean genotypes in Kenya. African Crop Science Journal 19:289302.

Waterer, D., J. Bantle, and T. Sander. 2003. Evaluation of row covers treatments for warm season crops. Saskatchewan Agriculture and Food, University of Saskatchewan, Saskatchewan, Canada. 8 Oct. 2014. <http://www.usask.ca/agriculture/ plantsci/vegetable/resources/veg/2003_microclimate_ ziptunnel.pdf $>$. 